\title{
Longitudinal Differences in Habitat Complexity and Fish Assemblage Structure of a Great Plains River
}

\author{
JEFFREY L. EITZMANN ${ }^{1}$ \\ Kansas Cooperative Fish and Wildlife Research Unit, Division of Biology, Kansas State University, \\ Manhattan 66506 \\ AND \\ CRAIG P. PAUKERT ${ }^{2}$ \\ U.S. Geological Survey, Kansas Cooperative Fish and Wildlife Research Unit, Division of Biology, \\ Kansas State University, Manhattan 66506
}

\begin{abstract}
We investigated the spatial variation in the Kansas River (USA) fish assemblage to determine how fish community structure changes with habitat complexity in a large river. Fishes were collected at ten sites throughout the Kansas River for assessing assemblage structure in summer 2007. Aerial imagery indicated riparian land use within $200 \mathrm{~m}$ from the river edge was dominated by agriculture in the upper river reaches $(>35 \%)$ and tended to increase in urban land use in the lower reaches $(>58 \%)$. Instream habitat complexity (number of braided channels, islands) also decreased with increased urban area $(<25 \%)$. Canonical correspondence analysis indicated that species that prefer high-velocity flows and sandy substrate (e.g., blue sucker Cycleptus elongatus and shovelnose sturgeon Scaphirhynchus platorynchus) were associated with the upper river reaches. Abundance of omnivorous and planktivorous fish species were also higher in the lower river. The presence of fluvial dependent and fluvial specialist species was associated with sites with higher water flows, more sand bars, and $\log$ jams. Our results suggest that conserving intolerant, native species in the Kansas River may require maintaining suitable habitat for these species and restoration of impacted areas of the river.
\end{abstract}

\section{INTRODUCTION}

River and stream habitat alteration has substantially affected lotic fishes throughout the world, causing declines of many native fishes and the homogenization of riverine fish communities (Rahel, 2000). For example, 17 species were extirpated from the Maumee River, Ohio and eight species from the Illinois River, Illinois (Karr et al., 1985). In addition, planktivores and omnivores became the dominant mid-river species following human influences on the watersheds. The major anthropogenic disturbances that caused these habitat and fish community alterations include agricultural land use, urbanization, channelization, dam construction, removal of snags and pollution (Johnson et al., 1995; Sparks, 1995; Richter et al., 1997). Many fluvial specialists (species that need flowing water habitats throughout their life cyle; Galat et al., 2005) and fluvial dependents (species that require flowing water for part of their life cycle; Galat et al., 2005) in Great Plains rivers have also been extirpated because of these anthropogenic disturbances (Karr et al., 1985; Pegg and McClelland, 2004; Galat et al., 2005). The reduction of these fluvial specialist and dependent species and homogenization of river fish communities makes it difficult to determine the more recent effects of anthropogenic disturbance on fish communities

\footnotetext{
${ }^{1}$ Present address: Miami-Dade County, Department of Environmental Resources Management, 701 NW $1^{\text {st }}$ Court, $6^{\text {th }}$ Floor, Miami, Florida 33136

${ }^{2}$ Corresponding author: email: cpaukert@ksu.edu
} 
(Rahel, 2000). Further, Bramblett and Fausch (1991) found that it is difficult to determine the status of fish communities in Great Plains streams and rivers because many of the species within these systems are tolerant generalists that occupy many habitats and can withstand many types of disturbances. Despite these impediments, assessing fish community responses to anthropogenic disturbance needs to be a priority to protect existing native species in large rivers.

Although many rivers have homogenized fish communities, spatial shifts in communities occur usually related to distinct habitat changes (e.g., dams, weirs, channelization; Pegg and McClelland, 2004; Pyron and Lauer, 2004; McClelland et al., 2006). For example, the Missouri and Illinois Rivers have been impacted by various human alterations, but species richness is highest in mid-river to downriver reaches as a result of greater numbers of tributaries in the lower Missouri River and the less impacted lower reaches of the Illinois River (Pegg and McClelland, 2004; Galat et al., 2005). Invertivores (fishes that feed on water column invertebrates) and herbivores (fishes that feed on plant material in the water column and substrate) are the most abundant trophic guilds in the upper reaches of the Missouri River, whereas omnivores and benthic invertivores (fishes that feed on bottom-dwelling invertebrates) become more abundant downstream (Pegg and Pierce, 2002; Galat et al., 2005). Shovelnose sturgeon Scaphirhynchus platorynchus and blue sucker Cycleptus elongatus prefer moderate to high velocity flows and specific habitats (Quist and Guy, 1999; Eitzmann et al., 2007) and had increased abundance in the relatively unimpacted upper Missouri River. Bigmouth buffalo Ictiobus bubalus, river carpsucker Carpiodes carpio and freshwater drum Aplodinotus grunniens are generalist fishes that prefer slow water and occur in the highly impacted, channelized lower river (Galat et al., 2005). McClelland et al. (2006) found that the lower Illinois River fish community consisted of mostly generalist species while the upper river fish community was composed of both generalist and specialist species. They also noted that predator abundance in the lower river was higher and forage fish abundance was higher in the upper reaches of the Illinois River. Karr et al. (1985) noted that mid-river omnivores became the dominant fishes in the Illinois River. Therefore, highly impacted areas of rivers tend to be dominated by omnivorous and generalist species.

The Kansas River has been impacted by human land use and management practices such as agriculture, channelization, levees, dredging and urbanization (Paukert and Makinster, 2008; Paukert et al., 2008), but little research has quantified the effects of these disturbances in altering the riverine fish community. There are 14 species that are listed by the state of Kansas as special concern, threatened or endangered including seven that are believed to be extirpated or no longer reproductively viable (Cross and Collins, 1995; Haslouer et al., 2005). Species such as the speckled chub Macrohybopsis aestivalis, plains minnow Hybognathus placitus and western silvery minnow Hybognathus argyritis were among the top ten most abundant species in the lower Kansas River in the 1950s, although their abundances were greatly diminished by 1980 (Cross and Moss, 1987). In addition, many other species also declined or disappeared from the lower Kansas River from 1950-1980 (e.g., pallid sturgeon, Scaphirhynchus albus, flathead chub Macrhybopsis gracilis, sicklefin chub Macrhybopsis meeki, sturgeon chub Macrhybopsis gelida, etc.; Cross and Moss, 1987). These examples, among others, suggest there have been substantial declines in native, fluvial specialist species in the Kansas River. The objective of this study was to quantify spatial fish community structure in the Kansas River and test for the effects from anthropogenic disturbance. We predicted the community structure near disturbed areas (i.e., reaches with more urban riparian area, above the Johnson County Weir and Bowersock Dam) would be dominated by macrohabitat 
generalist that can inhabit fast or slow moving water caused by distinct habitat changes and the creation of reservoir-like environments upstream of these structures (Gillette et al., 2005). We also hypothesized the Kansas River will be similar to the Missouri River with increased abundances of herbivores and invertivores in the upper, less impacted reaches, and the channelized lower portions of the river will contain more omnivores and benthic invertivores. Our prediction was that the lower, channelized river reaches contain higher abundances of macrohabitat generalist species, and the upper, relatively less impacted river would contain more fluvial specialist species.

\section{Methods \\ STUDY AREA}

The Kansas River is a shallow (typically $<1.5 \mathrm{~m}$ depth), sand substrate river that originates near Junction City, Kansas and flows east $274 \mathrm{~km}$ into the Missouri River (Makinster and Paukert, 2008). Although the watershed contains 18 federal reservoirs $(>650$ ha) and approximately 13,000 small impoundments, Bowersock Dam (a low-head dam at river kilometer, rkm 83) is the only dam partially restricting fish movement on the mainstem Kansas River (Quist and Guy, 1999). Bowersock Dam has created a low velocity, reservoir environment 5-6 km upstream. Additionally, Johnson County Weir (a small rock weir used to divert river flows associated with a water intake structure) at $\mathrm{rkm} 27$ may restrict fish movement at low discharge (Eitzmann et al., 2007) and creates a semi-reservoir environment for 5-6 km upstream. The upper river reaches are braided with multiple shallow side channels, and sandy islands that are usually overgrown with willows and grasses (Eitzmann $e t$ al., 2007).

\section{RIPARIAN AND INSTREAM HABITAT}

Ten reaches of the Kansas River were sampled for fishes and habitat (Table 1). Reaches were located at distances of approximately $32 \mathrm{~km}$ apart and selected to be representative of the entire Kansas River. The reach at Bowersock Dam was an exception where one reach was directly above the dam and another reach was directly below the dam. Within each reach, all sampling was conducted within a $6 \mathrm{~km}$ section (Table 1).

We used 1-m resolution aerial imagery from images taken on 24 Sep. 2006 to identify instream habitat (stream width, number of channels, and proportion as channel, grass islands and sand bars) and riparian land use (proportion as agriculture, forest and urban land use) in each reach (Paukert and Makinster, 2009). Transects were created perpendicular to the river channel at $0.8 \mathrm{~km}$ intervals within the ten reaches, and riparian habitat ( $200 \mathrm{~m}$ on each side of the bankfull height) was measured along the transect. We used geographic information systems (ArcGIS 9.2, Environmental Systems Research Institute, Redlands, CA) to calculate the length of each transect that was agriculture (pasture grassland and row cropland), forested (larger trees and vegetation) and urban land (obvious roads, paved parking lots, sand pits and other anthropogenic disturbances; Paukert and Makinster, 2009). Bankfull width (m) was calculated as the distance between the two most distinct banks along each transect (Paukert and Makinster, 2009). Within the bankfull width, the number of channels (areas containing flowing water), grass islands (grass and forested areas surrounded by water) and sand bars (sand and vegetated areas between the bankfull mark and the channel) were determined. The proportion of each instream habitat was estimated based on the proportion of that habitat relative to bankfill width. 


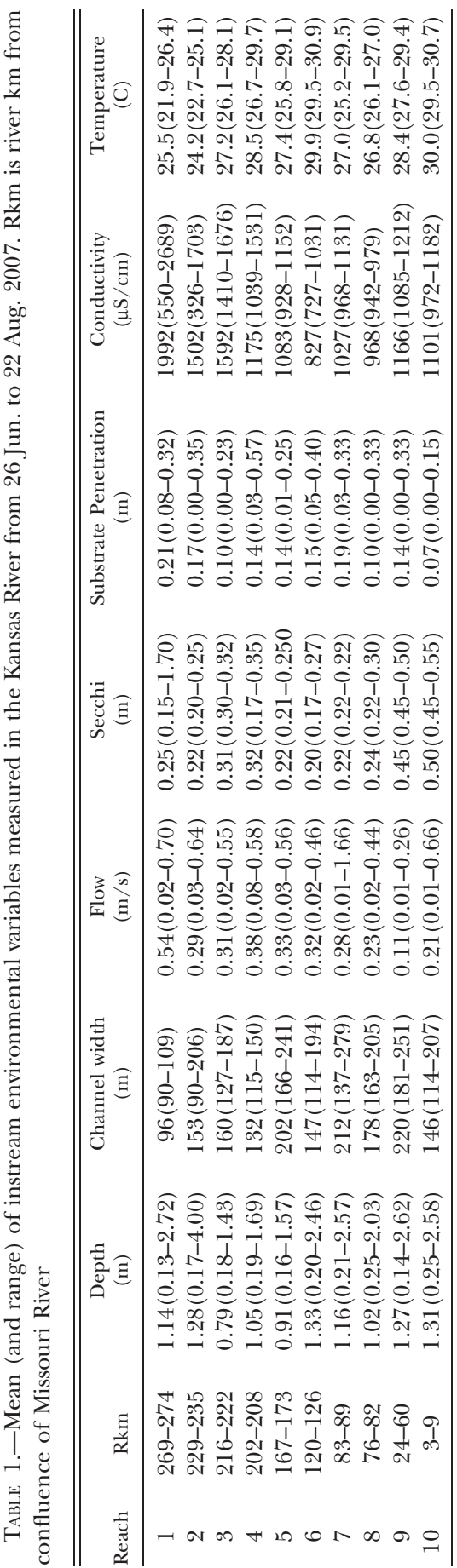




\section{FIELD COLLECTIONS}

The ten reaches were sampled for fishes and instream environmental variables from 26 Jun. to 22 Aug. 2007. Boat electrofishing and shoreline seining were used to assess the fish community as these gears collected $>90 \%$ of the species available (Eitzmann and Paukert, 2007). We attempted consistent effort in each reach for each gear to facilitate comparisons among reaches. Electrofishing was conducted in three habitats (main channel border, rock eddy and channel crossover) and seining was conducted in two habitats (main channel border and backwater) in each reach. We collected six randomly selected samples in each habitat with each gear at all reaches. If habitat was limited, all available habitat was sampled. Daytime pulsed DC electrofishing (7-11 A, 400-500 V, 40-60 pulses/s) was conducted for approximately $300 \mathrm{~s}$ for each sample in all habitats using a Coffelt Model VVP 15 electrofisher powered by a 5000-watt, single phase, 240-volt AC generator with a Wisconsin ring electrode with eight droppers attached to one boom. All electrofishing was conducted in $1 \mathrm{~d}$ at each reach. A $6.0 \mathrm{~m}$ long and $1.2 \mathrm{~m}$ deep straight seine with $0.64 \mathrm{~cm}$ mesh was fished parallel to shore for $25 \mathrm{~m}$ in all habitats to collect small-bodied fish. All seining was conducted in a single day in each reach. Fish collected with seines were euthanized and fixed with $10 \%$ formalin and identified in the laboratory. Twenty five individuals of each species in each sample was measured (total length, TL, mm) in the laboratory. All fish collected with electrofishing were identified, measured and released in the field near the site of collection.

We collected instream and shoreline environmental variable data at each site sampled with electrofishing and seining. The instream environmental variables collected include conductivity $(\mu \mathrm{S} / \mathrm{cm})$, depth $(\mathrm{m})$, flow (bottom, middle, surface velocity; $\mathrm{m} / \mathrm{s})$, Secchi depth $(\mathrm{cm})$, substrate penetration $(\mathrm{cm})$ and water temperature $(\mathrm{C})$. Water conductivity and temperature were collected with an YSI model $85 \mathrm{~m}$ (Yellow Spring Instruments, Inc, Yellow Springs, $\mathrm{OH}$ ). Water velocity was measured with a Marsh-McBirney Flow-mate 2000 (Marsh-McBirney, Loveland, CO). Shoreline environmental variables included visual proportion (within seine haul and electrofishing sites) of shoreline as mud bank, rip-rap, vegetation or woody debris. Depth (measured with a graduated rod or electronic depth finder), flow velocity and substrate penetration was quantified along three transects perpendicular to shore and three points were measured along each transect. Substrate penetration was measured by suspending a $3 \mathrm{~m}$ long, $1.3 \mathrm{~cm}$ diameter rebar $30 \mathrm{~cm}$ above the substrate, releasing it and then measuring the distance the rebar penetrated the substrate. Conductivity, Secchi depth and temperature were quantified at the beginning of each sample. Shoreline habitat was based on the shoreline present within each sample.

DATA ANALYSIS

A multivariate analysis of variance (MANOVA; SAS Institute, 2002) was used to test if the arcsine and square-root transformed mean proportion of riparian and instream habitat differed among reaches. If the MANOVA was significant an analysis of variance (ANOVA; Proc Mixed in SAS) was used to determine which habitat variables differed among sites (Littel et al., 1996). We selected a significance level of alpha $\leq 0.10$, and least squares means tests were used to determine where means differed if the ANOVA was significant.

Catch per unit of effort (CPUE) was calculated as catch per unit of area (e.g., fish $\left./ \mathrm{m}^{2}\right)$ for seines and catch per hour of electrofishing (i.e., fish/h). Canonical correspondence analysis (CCA) was used to examine patterns in species CPUE for each site to the variation in 13 environmental variables, the proportion of instream and riparian habitat, and 
distance from the Missouri River confluence (rkm). We used separate CCAs for seining and electrofishing. Only the species that accounted for $>1 \%$ of the total catch for each gear were used in the analysis (Ostrand and Wilde, 2002). The manual forward selection procedure in CANOCO 4.5 was used to decrease the number of environmental variables by only including the environmental variables that account for a significant amount of the variation $(\mathrm{P}<0.10)$ within the data set (ter Braak and Smilauer, 2002). The final CCA used the $\log _{10}$ transformed fish community data and the set of selected environmental variables. A CCA was also used to determine if feeding guild abundance was associated with environmental variables in the Kansas River. Species were assigned to a feeding guild based on Pflieger (1997) and Thomas et al. (2005; Table 2). We used the same methods for the CCA as above.

Principal components analysis (PCA) was conducted to determine which environmental variables best characterized the ten reaches. Each species was assigned a habitat guild and tolerance level based on Pflieger (1997), Galat et al. (2005) and Thomas et al. (2005; Table 2). We analyzed the seining and electrofishing data separately. We interpreted axes with eigenvalues greater than 1.0, which allows for the most important components to be retained (Kwak and Peterson, 2007), and used a multiple analysis of covariance (MANCOVA) to determine if mean principal component scores (for each axis) differed by the presence or absence of each guild (i.e., fluvial specialists, fluvial dependent, macrohabitat generalist, intolerant and tolerant species). River $\mathrm{km}$ was used as a covariate to account for spatial differences in the fish community. We chose to use the presence or absence of habitat or tolerance guild because of the few observations of each guild at a site. For example, $89 \%$ of the sites contained no fluvial specialists or intolerant species.

\section{RESULTS}

RIPARIAN AND INSTREAM HABITAT

The proportion of riparian land uses and instream habitat types differed among reaches (Wilks' lambda $=0.193$, d.f. $=36,327, \mathrm{P}<0.001)$. The upper river reaches $(1-3$ and 5 ) were dominated by agriculture and forested riparian areas with less than $10 \%$ urban area $(\mathrm{P}$ $<0.001$; Fig. 1A). Agricultural land use in the riparian area decreased from upriver to downriver with reach 10, near the urban area of Kansas City, Kansas, not containing any agricultural crops. The proportion of urban land use in the riparian area generally increased in a downstream direction (reaches $6-10$ ), with reaches $1-3$ having $<5 \%$ urban land use compared to $>20 \%$ urban land use in the riparian areas adjacent to reaches 7, 9 and $10(\mathrm{P}<0.001)$. Instream habitat (i.e., grass islands and sand bars) ranged from 25 to $40 \%$ in reaches $1-5$ and from 2 to $25 \%$ in reaches $6-10$ (Fig. 1B). Mean channel width ranged from 171 to $332 \mathrm{~m}$ in reaches $1-5$ and was 156 to $267 \mathrm{~m}$ in reaches $6-10$ (Fig. 2C; $\mathrm{P}$ $=0.006)$. The mean number of channels tended to be higher in the upper river (1.4 to 1.8 channels in reaches 1-5 compared to 1.0 tol.4 channels in reaches $6-10$ (Fig. 2C), but was not statistically different among reaches $(\mathrm{P}=0.204)$.

In the reach immediately above Bowersock Dam (reach 7) the area had increased urban land use compared to adjacent reaches (Fig. 1A; P $<0.001$ ). A decrease in instream habitat was also evident in reach 7 with relatively fewer secondary channels (Fig. 1B, C). There was an increase in the mean channel widths between Bowersock Dam and the Johnson County Weir similar to the upriver reaches 3 and 4 (Fig. 1C; $\mathrm{P}<0.001$ ). The riparian area below the Johnson County Weir was dominated by urban land use, and instream habitat was almost nonexistent with a narrow and relatively unbraided channel (Fig. 1A, B). 
TABLE 2.-Habitat guild, feeding guild and tolerance level of all species captured in seine and electrofishing sites in the Kansas River in summer 2007 (Pflieger, 1997; Galat et al., 2005; Thomas et al., 2005). Species codes are given for the species used in canonical correspondence analysis (Figs. 2 and 3)

\begin{tabular}{|c|c|c|c|c|}
\hline Species & Species code & Habitat guild & Feeding guild & Tolerance \\
\hline Bigmouth buffalo & & Macrohabitat generalist & Planktivore & \\
\hline Black crappie & & Macrohabitat generalist & Invertivore & \\
\hline Blue catfish & & Fluvial specialist & Omnivore & \\
\hline Bluegill & & Macrohabitat generalist & Invertivore & \\
\hline Blue sucker & Cycelo & Fluvial specialist & Invertivore & Intolerant \\
\hline Bullhead minnow & Pimvig & Macrohabitat generalist & Omnivore & \\
\hline Bluntnose minnow & Pimnot & Macrohabitat generalist & Detritivore & Tolerant \\
\hline Creek chub & & Macrohabitat generalist & Invertivore & Tolerant \\
\hline Channel catfish & Ictpun & Macrohabitat generalist & Omnivore & \\
\hline Common carp & Cypcar & Macrohabitat generalist & Detritivore & Tolerant \\
\hline Central stoneroller & & Fluvial specialist & Herbivore & \\
\hline Emerald shiner & Notath & Macrohabitat generalist & Planktivore & \\
\hline Fathead minnow & & Macrohabitat generalist & Detritivore & Tolerant \\
\hline Flathead catfish & Pyloli & Fluvial dependent & Piscivore & \\
\hline Freshwater drum & Aplgru & Macrohabitat generalist & Invertivore & \\
\hline Goldeye & & Fluvial dependent & Invertivore & Intolerant \\
\hline Green sunfish & & Macrohabitat generalist & Invertivore & Tolerant \\
\hline Gizzard shad & Dorcep & Macrohabitat generalist & Detritivore & \\
\hline Johnny darter & & Macrohabitat generalist & Invertivore & \\
\hline Longear sunfish & & Macrohabitat generalist & Invertivore & \\
\hline Largemouth bass & & Macrohabitat generalist & Piscivore & \\
\hline Longnose gar & Leposs & Fluvial dependent & Piscivore & \\
\hline Orangespotted sunfish & & Macrohabitat generalist & Invertivore & \\
\hline Quillback & & Macrohabitat generalist & Detritivore & \\
\hline River carpsucker & Carcar & Macrohabitat generalist & Detritivore & \\
\hline Redfin shiner & & Fluvial specialist & Invertivore & Intolerant \\
\hline Red shiner & Cyplut & Macrohabitat generalist & Omnivore & \\
\hline Smallmouth bass & & Macrohabitat generalist & Piscivore & Intolerant \\
\hline Smallmouth buffalo & Ictbub & Macrohabitat generalist & Detritivore & \\
\hline Shorthead redhorse & & Fluvial dependent & Invertivore & \\
\hline Shortnose gar & & Macrohabitat generalist & Piscivore & \\
\hline Shovelnose sturgeon & Scapla & Fluvial specialist & Invertivore & Intolerant \\
\hline Suckermouth minnow & Phemir & Fluvial specialist & Invertivore & \\
\hline Sand shiner & Notstr & Fluvial specialist & Omnivore & \\
\hline White bass & Morchy & Fluvial dependent & Piscivore & \\
\hline White bass hybrid & Morchy hyb & Fluvial dependent & Piscivore & \\
\hline White crappie & Pomann & Macrohabitat generalist & Piscivore & \\
\hline White sucker & & Fluvial dependent & Detritivore & Tolerant \\
\hline Western mosquitofish & Gamaff & Macrohabitat generalist & Invertivore & \\
\hline
\end{tabular}

\section{FIELD COLLECTIONS}

A total of 334 fishes were captured in the electrofishing samples (21 species, 146 electrofishing transects; Table 3) and 13,490 fishes were captured in seine samples (30 species, 83 seine hauls; Table 3) in the Kansas River in summer 2007. Electrofishing samples yielded eight unique species (i.e., species only captured with this gear) and seine sampled yielded 18 unique species (Table 3). Electrofishing samples consisted of $85.3 \%$ large-bodied 

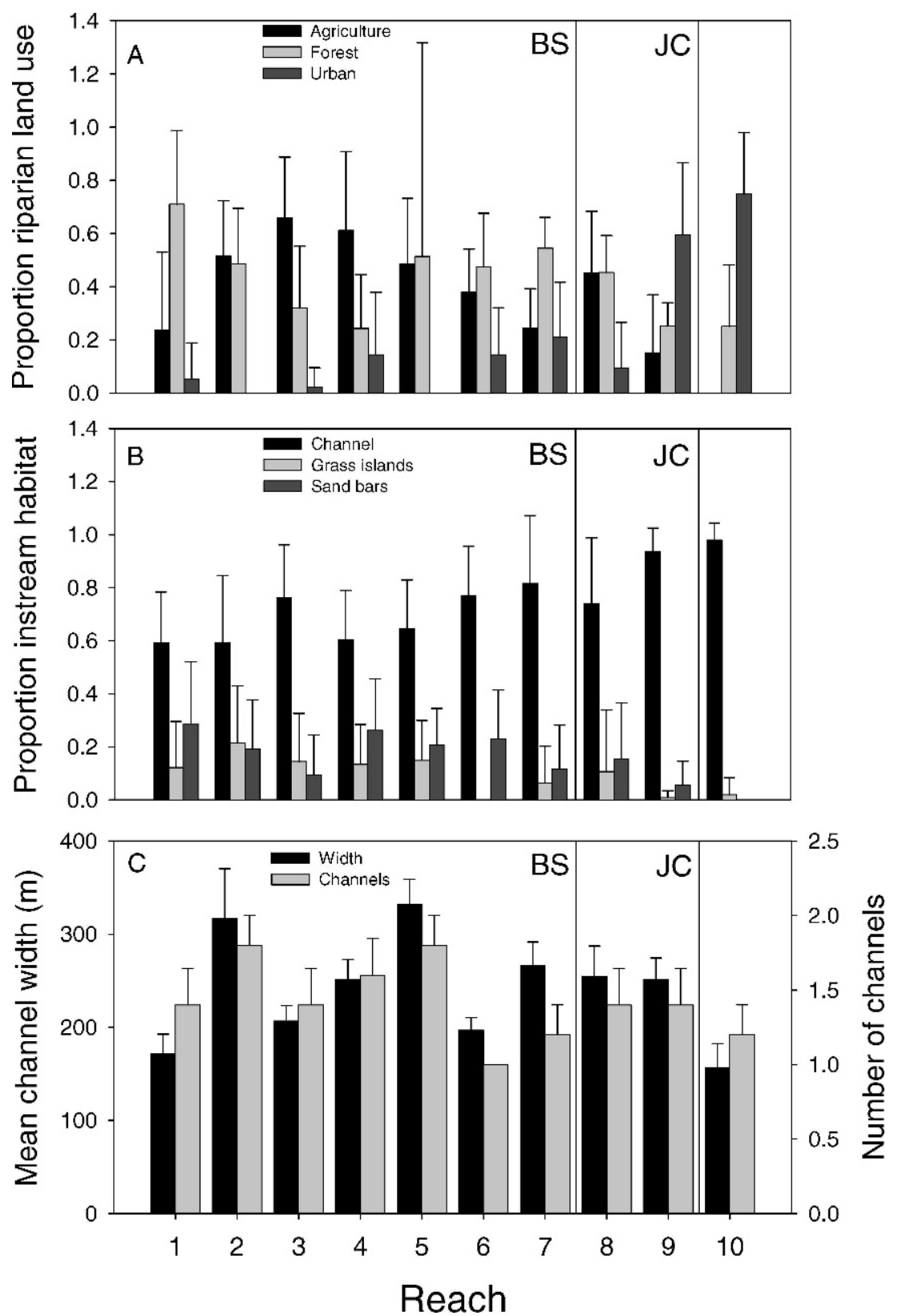

FIG. 1.-Mean proportion ( $\pm \mathrm{SE}$ ) of (A) riparian land use, (B) instream habitat type and (C) mean width $(\mathrm{m})$ and number of channels within each reach sampled in the Kansas River from satellite imagery data from Sep. 2006. The solid lines represent Bowersock Dam (BS) and the Johnson County Weir (JC) 

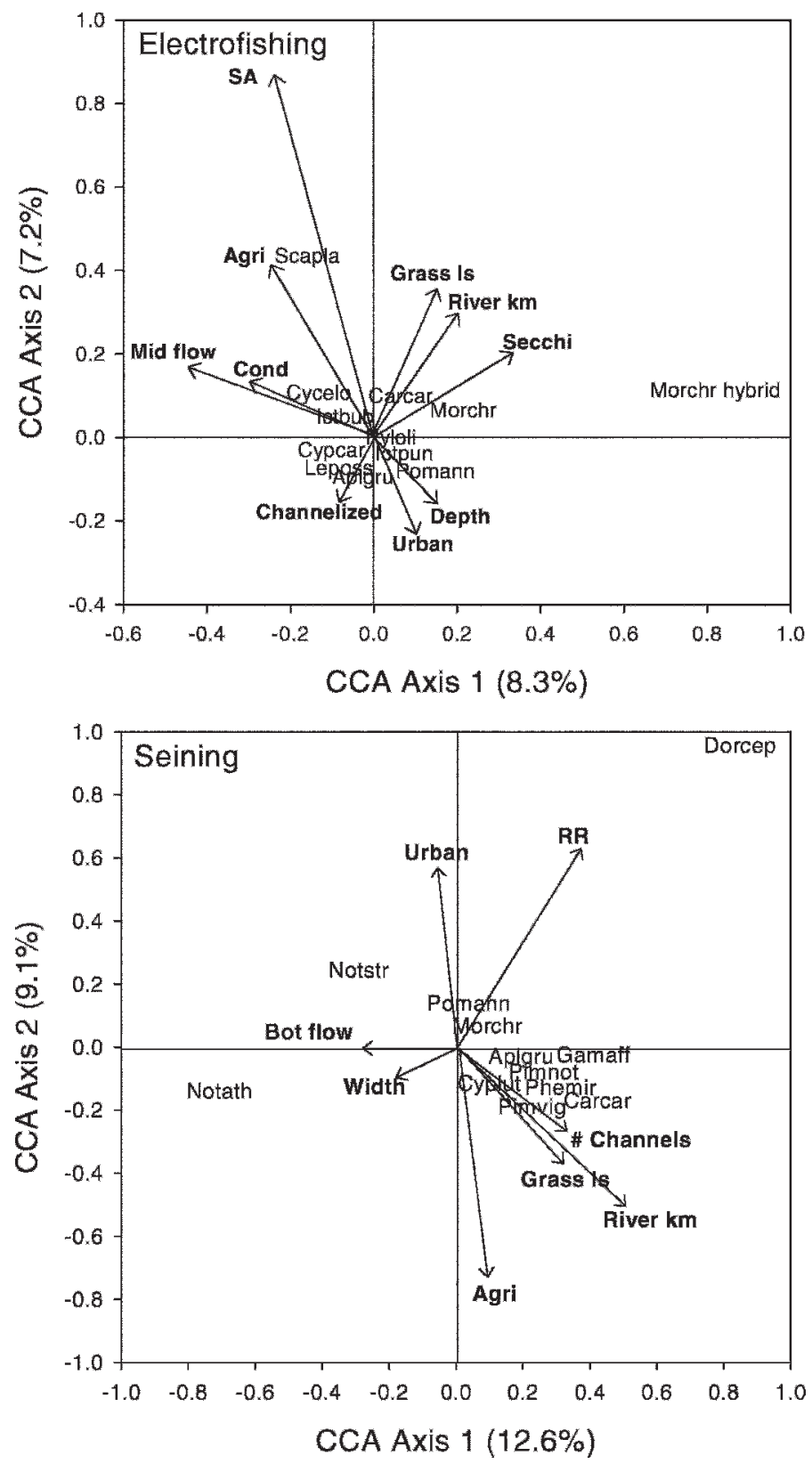

Fig. 2.-Canonical correspondence analysis of $\log 10$-transformed relative abundance of species for the electrofishing samples and seine samples collected in the Kansas River in summer 2007 and how they are explained by riparian and instream environmental variables. Species names are shown in Table 2. The environmental variables include; proportion of agricultural land use (Agri), mean bottom water column flow (Bot flow), mean middle water column flow (Mid flow), the proportion of the bankfull width that is main channel (Channelized), the mean number of channels (\# Channels), 
individuals (TL $>100 \mathrm{~mm}$ ) and seine samples consisted of $99.8 \%$ small bodied individuals (TL $<100 \mathrm{~mm})$. The dominant species captured with electrofishing $(75.1 \%$ of the total catch) included common carp Cyprinus carpio, flathead catfish Pylodictis olivaris, freshwater drum, river carpsucker and white crappie Pomoxis annularis. The dominant species captured with the seine $(91.5 \%$ of the total catch) included bullhead minnow Pimephales vigilax, river carpsucker, red shiner Cyprinella lutrensis and sand shiner Notropis stramineus. Seine samples in reach 7 and 10 consisted of $<20 \%$ red shiner, whereas all other reaches were $>44 \%$ red shiner (Table 3). In addition, seine samples collected in reach 10 had an increased proportion of gizzard shad Dorosoma cepedianum (22\%) compared to other reaches (0-6\%). Reach 7 also had a high proportion of white crappie (22\%) in the electrofishing samples compared to other reaches $(0-7 \%)$.

Total variation explained by all CCA axis from the electrofishing species data was $28.1 \%$, with axis one explaining $8.3 \%$ of the variation and axis 2 explaining $7.2 \%$ of the variation (Fig. 2). The CCA axes were significantly different than random $(P=0.002)$. Species associated with increased agricultural land use included blue sucker, shovelnose sturgeon and smallmouth buffalo Ictiobus bubalus. These areas consisted of increased sand bars, conductivity and higher velocity flows (Table 1; Fig. 2). The lower river had a higher proportion of channel catfish Ictalurus punctatus, common carp, freshwater drum and longnose gar Lepisosteus osseus. These reaches were characterized by fewer sand bars and deeper, channelized areas (Table 1; Fig. 2). Total variation explained by the species data for the seine samples CCA was $34.7 \%$, with axis 1 explaining $12.6 \%$ and axis 2 explaining $9.1 \%$ of the variation in the species data. The CCA axes were significantly different than random $(\mathrm{P}=0.002)$. Gizzard shad were found in areas with rip-rap banks and an increased urban land use. Sand shiner was the dominant species in the lower river reaches. The upriver sites consisted mostly of red shiner, Western mosquitofish Gambusia affinis, bluntnose minnow Pimephales notatus and bullhead minnow. These sites were characterized with greater proportion of agricultural land and instream habitat complexity (Fig. 2). The lower reservoir-like reach (7) and the highly modified reaches (9 and 10) were characterized by rip-rap banks, and urban and channelized areas (Fig. 1). Reach 8 (directly below Bowersock Dam) consisted of urban and agricultural riparian areas and was intermediate in the proportion of that reach that was channelized and contained sand bars (Fig. 1)

The proportional abundance of feeding guilds collected by electrofishing indicated that omnivorous species were associated with the lower, impacted reaches (Fig. 3). Total variation explained in the CCA by the feeding guild data for the electrofishing samples was $14.3 \%$, with axis 1 explaining $6.5 \%$ and axis 2 explaining $5.4 \%$ of the variation in the species data. The CCA axes were significantly different than random $(P=0.004)$. The omnivores were associated with the reaches with a higher proportion of channelization in lower river reaches. The insectivores tended to be associated with higher proportions of sand bars, but were found throughout the river. The seining data CCA also showed similar patterns (Fig. 3). Total variation explained by the feeding guild data for the seine samples was $34.8 \%$, with axis 1 explaining $20.4 \%$ and axis 2 explaining $9.7 \%$ of the variation in the species data

conductivity (Cond.), mean depth (Depth), the proportion of instream habitat as grass islands (Grass Is), the proportion of the shoreline habitat as rip-rap habitat (RR), river kilometer from Missouri River confluence (River $\mathrm{km}$ ), the proportion of the shoreline habitat as sand bar habitat (SA), Secchi depth (Secchi), the proportion of urban land use (Urban) and mean bankfull width (Width) 


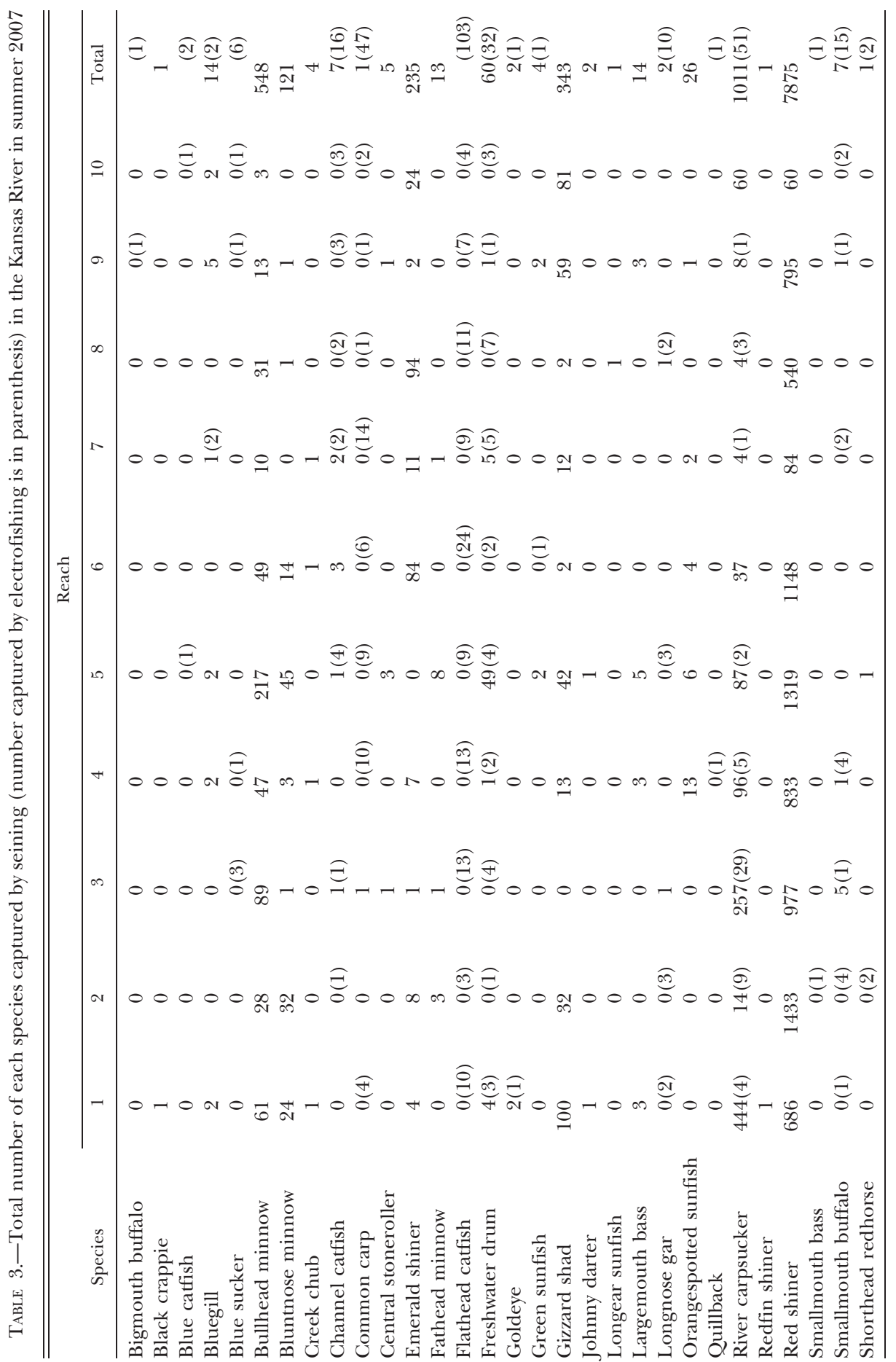




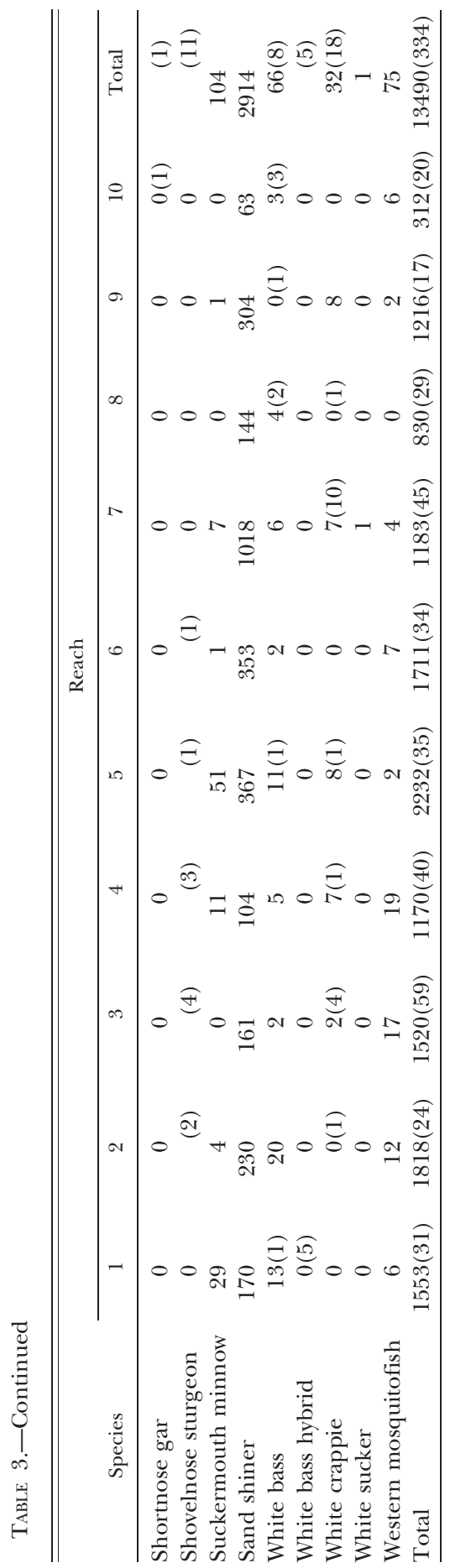



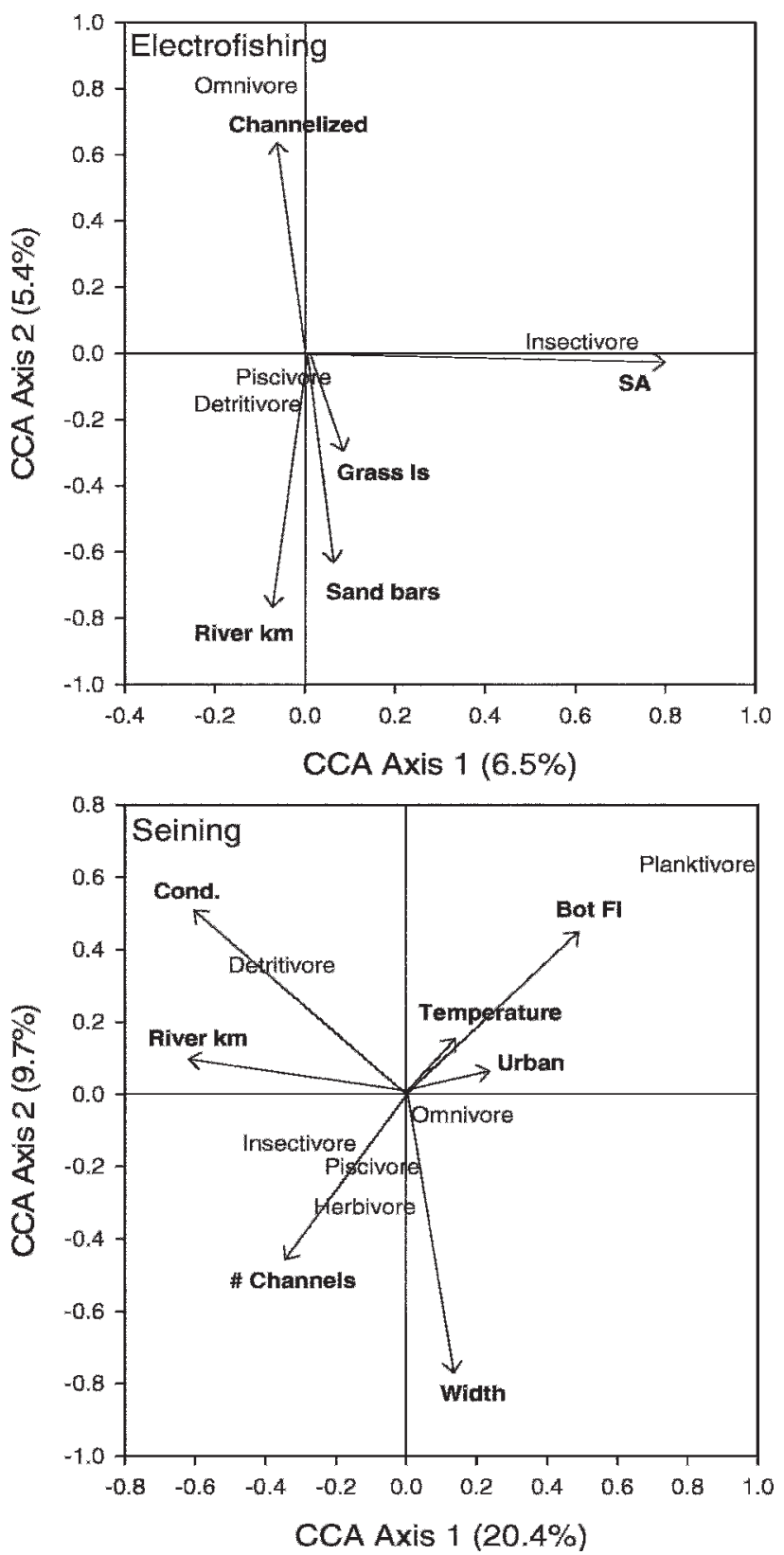

Fig. 3.-Canonical correspondence analysis of $\log 10$-transformed relative abundance of feeding guilds for fishes collected from the electrofishing samples and seine samples collected in the Kansas River in summer 2007, and how they were explained by riparian and instream environmental variables and reach. The feeding guilds include; detritivores, herbivores, invertivores, omnivores and piscivores. The environmental variables include; mean bottom water column flow (Bot flow), the proportion of the river as main channel (Channelized), the mean number of channels (\# Channels), conductivity 
TABLE 4.-Component loadings from two principal components analyses (PCA) using shoreline and instream environmental variables collected in the Kansas River in summer 2007. Separate PCAs were conducted for electrofishing and seining

\begin{tabular}{lrrrrrrrr}
\hline \hline & \multicolumn{3}{c}{ Electrofishing } & & \multicolumn{3}{c}{ Seining } \\
\cline { 2 - 5 } \cline { 7 - 8 } \multicolumn{1}{c}{ Variable } & Habitat 1 & Habitat 2 & Habitat 3 & & Habitat 1 & Habitat 2 & Habitat 3 \\
\hline Proportion shoreline rip-rap & -0.26 & 0.62 & -0.01 & & 0.12 & -0.43 & -0.08 \\
Proportion shoreline log jam & 0.04 & -0.37 & 0.71 & & -0.07 & -0.03 & 0.84 \\
Proportion shoreline sand bar & 0.37 & -0.17 & -0.52 & & -0.04 & 0.56 & 0.12 \\
Depth (m) & -0.31 & 0.16 & 0.05 & & -0.08 & -0.21 & -0.40 \\
Bottom flow (m/s) & 0.32 & 0.26 & -0.20 & & 0.56 & 0.08 & 0.06 \\
Mid-water flow (m/s) & 0.50 & 0.24 & 0.27 & & 0.57 & 0.08 & -0.01 \\
Surface flow (m/s) & 0.50 & 0.26 & 0.27 & & 0.57 & 0.07 & -0.02 \\
Secchi depth (m) & -0.28 & -0.10 & 0.01 & & 0.11 & -0.50 & 0.03 \\
Substrate penetration (m) & 0.16 & -0.47 & -0.18 & & -0.05 & 0.44 & 0.34 \\
Eigenvalue & 2.77 & 1.62 & 1.29 & & 2.98 & 2.03 & 1.10 \\
Variance Explained (\%) & 31 & 18 & 14 & & 33 & 22 & 12 \\
\hline
\end{tabular}

(Fig. 3). Planktivores were associated with the reaches with increased urban land use in the riparian area and higher bottom water velocities that tended to be downstream reaches. Herbivores, insectivores and piscivores were associated with the upper river reaches and areas with increased number of channels (Fig. 3). Detritivores were also associated with the upper river reaches and areas of high conductivity. Therefore, omnivores (electrofishing) and planktivores (seining) were associated with impacted areas with increased urbanization in the riparian area and channelization.

The habitat PCA of electrofishing data indicated that PC 1 was an index of increased flows, sand bar habitat and decreased depth and accounted for $31 \%$ of the variation among sites (Table 4). Sites with high component loadings on axis 2 consisted of high proportion rip rap and deeper substrate penetration and explained $18 \%$ of the variation among sites electrofished (Table 4). Sites that scored high on axis 3 had a high proportion of log jams and low proportion of sand bars. The mean PC 1, PC 2 and PC 3 scores differed between samples with the presence of fluvial specialists (Wilks' lambda $=0.916$ d.f. $=3,136, \mathrm{P}=$ 0.007 ), fluvial dependents (Wilks' lambda $=0.827$, d.f. $=3,136, \mathrm{P}<0.001$ ), macrohabitat generalists (Wilks' lambda $=0.847$, d.f. $=3,136, \mathrm{P}<0.001$, intolerant species (Wilks' lambda $=0.937$, d.f. $=3,136, \mathrm{P}=0.032$ ) and tolerant species (Wilks' lambda $=0.934$, d.f. $=3,78, \mathrm{P}=0.027$ ). Mean PC 1 scores (increased flows and sand bars) was higher when fluvial specialists and intolerant species were present (Fig. 4). The presence of fluvial dependents at a site was related to lower PC 1 scores (i.e., increased flows and sand bars), PC 2 scores (increased substrate penetration and lower rip rap) and higher PC 3 scores (more $\log$ jams, Fig. 4). The presence of macrohabitat generalists was associated with lower PC 1 scores and higher PC 3 scores (Fig. 4). The presence of intolerant species was strongly related to sites that scored higher on PC 1 and, therefore, had higher flows and higher

(Cond.), the proportion of instream habitat as grass islands (Grass Is), the proportion of the shoreline habitat as sand bar habitat (SA), river kilometer from Missouri River confluence (River $\mathrm{km}$ ), the proportion of instream habitat as sand bars (sand bars), mean temperature, the proportion of urban land use (Urban) and mean river width (Width) 

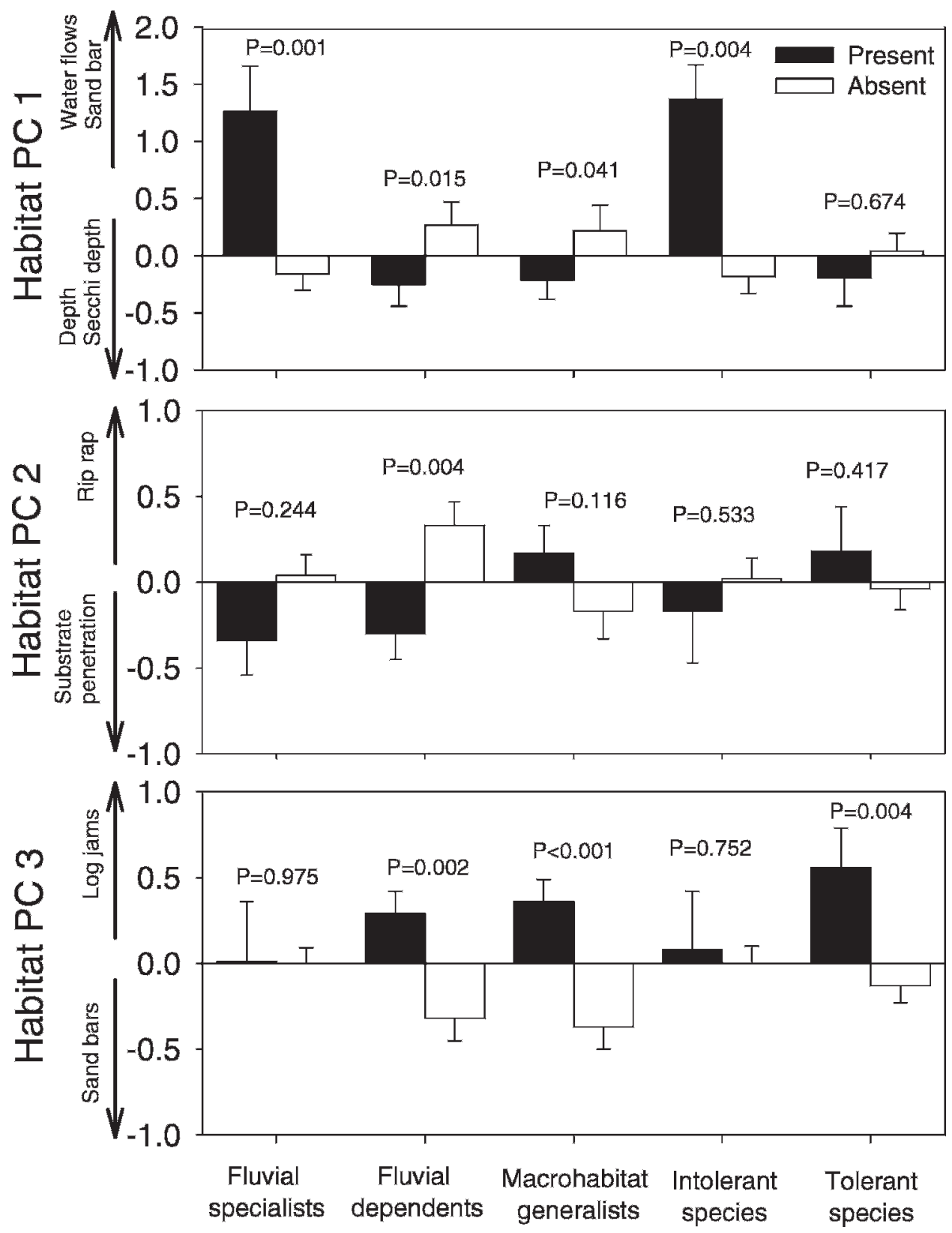

FIG. 4.- Mean principal component axes score $( \pm \mathrm{SE})$ with the presence and absence of three habitat guild and tolerance level for fishes captured with electrofishing. P-values are from the individual ANOVAs after a significant MANCOVA 
frequencies of sand bar habitat. The presence of tolerant species was most strongly related to higher PC 3 scores and thus increased log jams at a site (Fig. 4).

The habitat PCA of the seining data showed that sites that scored high on PC 1 had high flows and this axis accounted for $33 \%$ of the variation among sites (Table 4). Axis 2 was a gradient of increased sand bars and substrate compaction, and decreased rip rap and Secchi depth (Table 4). Axis 3, which explained 12\% of the variation, was primarily an axis of increased log jams. The mean PC 1, PC 2 and PC 3 scores did not differ among samples with fluvial specialists (Wilks' lambda $=0.938$, d.f. $=3,79, \mathrm{P}=0.172$ ), fluvial dependents (Wilks' lambda $=0.953$, d.f. $=3,78, \mathrm{P}=0.289$ ), intolerant species (Wilks' lambda $=0.975$, d.f. $=3$, $78, \mathrm{P}=0.567$ ) or tolerant species (Wilks' lambda $=0.921$, d.f. $=3,78, \mathrm{P}=0.092$ ). Macrohabitat generalists were present in every site.

\section{Discussion}

Land use and instream habitat alterations can cause significant changes in fish community structure (Karr et al., 1985; Roth et al., 1996; McClelland et al., 2006) and it is important for conservation and management to determine the effects of these alterations on the fish community. In the Kansas River instream and riparian habitat differed longitudinally changing from diverse habitat areas to channelized, urban-dominated areas. In the lower river, deeper and narrower channels with fewer braided channels and islands were present, which is consistent with Paukert and Makinster (2009) who documented homogeneous habitats in the urban reaches of the Kansas River. The reduction of instream habitat in mid to lower reaches of the Kansas River suggests homogenization of the habitats (Lenat and Crawford, 1994; May et al., 1997; Paukert and Makinster, 2009) and was linked to the fish community variation.

Great Plains river fish communities consist of many species that are tolerant or moderately tolerant to a wide range of physicochemical conditions (Cross and Moss, 1987; Bramblett and Fausch, 1991; Fausch and Bramblett, 1991). Our study found changes in habitat were associated with changes in fish communities even within this relatively homogeneous assemblage. However, large-bodied fish presence and species composition tended to vary longitudinally. Localized structures that cause disturbances such as Bowersock Dam (reach 7) and the Johnson County Weir (reach 10) in the lower urban area near Kansas City, Kansas resulted in more dissimilar fish assemblages, suggesting that these barriers are affecting the fish community. Low-head dams may cause localized reservoir effects above dams and, therefore, impact the fish community directly above dams and result in dominance by lentic fish species (Gillette et al., 2005). The fish community in the reaches between Bowersock Dam and the Johnson County Weir were similar to the upper Kansas River, likely due to the increased frequency of secondary channels. The site below the Bowersock Dam appears to be a reset point, changing the fish community composition to more riverine species below the dam (Ward and Stanford, 1983).

Subtle longitudinal differences in fish communities may be related to habitat modification. The lower Kansas River consisted of channel catfish, freshwater drum, common carp, longnose gar and white crappie, which are species that prefer low velocity habitats (Cross and Collins, 1995; Pflieger, 1997). Species that preferred low velocity habitats in the Missouri River were in highest abundance in the lower and highly impacted areas of the river (Galat et al., 2005), which is consistent with this study. The upper Kansas River reaches were dominated by blue sucker, river carpsucker, smallmouth buffalo, shovelnose sturgeon, bluntnose minnow, bullhead minnow, red shiner and Western mosquitofish. Shovelnose sturgeon and blue sucker prefer high velocity habitats (Galat et al., 
2005) and had the highest abundances in the upriver reaches suggesting the diverse habitat and increased flows are beneficial to these large river obligate species (Quist and Guy, 1999; Eitzmann et al., 2007). In the Wabash River, Indiana, fish species that preferred sand substrates and had body morphologies suitable for higher water velocities were found in higher abundance in the upper, less impacted portions of the river (Pyron and Lauer, 2004). Smallmouth buffalo, bluntnose minnow, bullhead minnow, red shiner and western mosquitofish tended to inhabit multiple locations, but other sources claim they prefer habitats of lower velocity (Cross and Collins, 1995; Pflieger, 1997). This suggests suitable habitat diversity in the upper reaches of the Kansas River that results in higher abundance of riverine species.

Omnivores were associated with the lower channelized reaches of the Kansas River. In highly impacted rivers, different feeding guilds tend to occupy different areas of the river (Pegg and Pierce, 2002; Galat et al., 2005; McClelland et al., 2006) suggesting that changes in habitat in the impacted areas affects species and guild composition in large rivers (Paukert $e t$ $a l .$, 2008). In the Missouri River herbivores and invertivores were in higher abundance in the upper unchannelized river and omnivores and benthic invertivores were in higher abundance in the lower highly impacted area of the river (Pegg and Pierce, 2002; Galat $e t$ al., 2005), which is similar to our study.

Moderately tolerant and tolerant fish species comprised $87 \%$ of the fish community in the Kansas River with $71 \%$ of the tolerant species sampled macrohabitat generalists. However, the relatively few large-bodied intolerant and fluvial specialists fish species were typically associated with upper river reaches that had increased frequencies of sand bars and highvelocity habitats, suggesting these areas are important to intolerant species. Within the Kansas River, 14 species are listed as state or federally endangered, threatened or of special concern (Cross and Collins, 1995; Haslouer et al., 2005). Of the listed species only one (blue sucker) was collected, suggesting the other species were extirpated from the river or occur in relatively low abundance. Ten of the 14 species historical ranges in the Kansas River included the lower river, which is the most impacted segment of the Kansas River (Paukert $e t$ $a l .$, 2008). It was not surprising that we collected none of these species. We did not capture any of the species that were among the top 10 abundant fishes in 1950 (plains minnow, speckled chub and western silvery minnow; Cross and Moss, 1987). The channelized lower river impacts created a homogeneous fish community dominated by tolerant generalist species. These habitat changes, coupled with species introductions, contribute to the homogenization of fish faunas (Rahel, 2000). Currently the two intolerant species (blue sucker and shovelnose sturgeon) that we captured in high abundance were captured in the upper river reaches that were less impacted by urbanization and channelization. Therefore, preserving the integrity of the upper river may be important for the survival of these species and other large river fishes. However, restoration efforts in the lower river need to be considered in the context of high urbanization and invasive species introductions.

Acknowledgments. -We thank Luke Kowalewski, Andy Makinster, Miles Thompson and Tony Ferlage for there help with field and laboratory data collection. We also thank Walter Dodds, Nate Franssen, Keith Gido and two anonymous reviewers for providing beneficial comments on the manuscript. Also, we thank Kristen Hase and Mark Van Scoyoc for providing funding for this project was through the Kansas Department of Wildlife and Parks State Wildlife Grant T-15-R-1. The Kansas Cooperative Fish and Wildlife Research Unit is jointly sponsored by the Kansas Department of Wildlife and Parks, Kansas State University, the U.S. Geological Survey and the Wildlife Management Institute. The use of trade, product, industry or firm names or products is for informative purposes only and does not constitute an endorsement by the U.S. government, the U.S. Geological Survey or other sponsoring or participating agencies. 


\section{Literature Cited}

Bramblett, R. G. and K. D. Fausch. 1991. Variable fish communities and the index of biotic integrity in a Western Great Plains River. Trans. Am Fish. Soc., 120:752-769.

Cross, F. B. ANd J. T. Collins. 1995. Fishes in Kansas, 2nd ed. University of Kansas Press, Lawrence, Kansas. 336 p.

AND R. E. Moss. 1987. Historic changes in fish communities and aquatic habitat in plains streams of Kansas, p. 155-165. In: W. J. Matthews and D. C. Heins (eds.). Community and evolutionary ecology of North American stream fishes. University of Oklahoma Press, Norman, Oklahoma. $310 \mathrm{p}$.

Eitzmann, J. L., A. S. Makinster and C. P. Paukert. 2007. Distribution and growth of blue suckers in a Great Plains river, USA. Fish. Manage. and Ecol., 14:255-262.

—, ANd C. P. Paukert. 2007. Distribution and abundance of fishes in the Kansas River. Kansas Department of Wildlife and Parks, Report T-15-R-1. 16 p.

Fausch, K. D. and R. G. BRamblett. 1991. Disturbance and fish communities in intermittent tributaries of a western Great Plains river. Copeia, 1991:657-672.

Galat, D. L., C. R. Berry, W. M. Gardner, J. C. Hendrickson, G. E. Mestl, G. J. Power, C. Stone and M. R. Winston. 2005. Spatiotemporal patterns and changes in Missouri River fishes, p. 249-291. In: J. N. Rinne, R. M. Hughes and B. Calamusso (eds.). Historical changes in large river fish assemblages of the Americas. American Fisheries Society, Bethesda, Maryland. 612 p.

Gillette, D. P., J. S. Tiemann, D. R. Edds and M. L. Wildhaber. 2005. Spatiotemporal patterns of fish assemblage structure in a river impounded by low-head dams. Copeia, 2005:539-549.

Haslouer, S. G., M. E. Eberle, D. R. Edds, K. B. Gido, C. S. Mammoliti, J. R. Triplett, J. T. Collins, D. A. Distler, D. G. Huggins and W. J. Stark. 2005. Current status of native fish species in Kansas. Trans. Kan. Acad. Sci., 108(1/2):32-46.

Johnson, B. L., W. B. Richardson and T. J. Naimo. 1995. Past, present, and future concepts in large river ecology. BioScience, 45:134-141.

KarR, J. R., L. A. Toth and D. R. Dudley. 1985. Fish communities of Midwestern rivers: a history of degradation. BioScience, 35:90-95.

Kwak, T. J. and J. T. Peterson. 2007. Community indices, parameters, and comparisons, p. 677-764. In: C. S. Guy and M. L. Brown (eds.). Analysis and interpretation of freshwater fisheries data. American Fisheries Society, Bethesda, Maryland. 961 p.

Lenat, D. R. AND J. K. CrawFord. 1994. Effects of land use on water quality and aquatic biota of three North Carolina piedmont streams. Hydrobiologia, 294:185-199.

Littel, R. C., G. A. Milliken, W. W. Stroup and R. D. Wolfinger. 1996. SAS System for Mixed Models. SAS Institute, Cary, North Carolina. 811 p.

Makinster, A. S. and C. P. Paukert. 2008. Effects and utility of minimum length limits and mortality caps for flathead catfish in discrete reaches of a large prairie river. North Am. J. Fish. Mgmt., 28:97-108.

May, C. W., R. R. Horner, J. R. KarR, B. W. Mar and E. B. Welch. 1997. Effects of urbanization on small streams in the Puget Sound Lowland Ecoregion. Watershed Prot. Tech., 2:485-494.

McClelland, M. A., M. A. Pegg and T. W. Spier. 2006. Longitudinal patterns of the Illinois Waterway Fish Community. J. Fresh. Ecol., 21:91-99.

Ostrand, K. G. and G. R. Wilde. 2002. Seasonal and spatial variation in a prairie stream-fish assemblage. Ecol. Freshw. Fish, 11:137-149.

Paukert, C. P. and A. S. Makinster. 2009. Longitudinal patterns in flathead catfish abundance and growth within a large river: effects of an urban gradient. River Res. and Appl., 25:861-873. DOI $10.1002 /$ rra.1089.

— - J. Schloesser, J. Fischer, J. Eitzmann, K. Pitts and D. Thornbrugh. 2008. Effects of instream sand dredging on fish communities in the Kansas River USA: current and historical perspectives. $J$. Fresh. Ecol., 23:623-633.

Pegg, M. A. and M. A. McClelland. 2004. Spatial and temporal patterns in fish communities along the Illinois River. Ecol. Freshw. Fish, 13:125-135. 
AND C. L. PIERCE. 2002. Fish community structure in the Missouri and lower Yellowstone rivers in relation to flow characteristics. Hydrobiologia, 479:155-167.

Pflieger, W. L. 1997. The Fishes of Missouri. Revised edition. Missouri Department of Conservation, Jefferson City, Missouri. 377 p.

Pyron, M. and T. E. Lauer. 2004. Hydrological variation and fish assemblage structure in the middle Wabash River. Hydrobiologia, 525:203-213.

QUIST, M. C. AND C. S. GuY. 1999. Spatial variation in population characteristics of shovelnose sturgeon in the Kansas River. Prairie Nat., 31:65-74.

RAHEL, F. J. 2000. Homogenization of fish faunas across the United States. Science, 288:854-856.

Richter, B. D., D. P. Braun, M. A. Mendelson and L. L. Master. 1997. Threats to imperiled freshwater fauna. Cons. Biol., 11:1081-1093.

Roth, N. E., J. D. Allan and D. L. Erickson. 1996. Landscape influences on stream biotic integrity assessed at multiple spatial scales. Landscape Ecol., 11:141-156.

SAS Institute Inc. 2002. SAS system for statistical analysis. Version 9.1. SAS Institute Inc., Cary, North Carolina. 176 p.

Sparks, R. E. 1995. Need for ecosystem management of large rivers and their floodplains. Bioscience, 45:168-182.

ter Braak, C. J. F. and P. Smilauer. 2002. Canoco reference manual and CanoDraw for Windows user's guide: software for canonical community ordination, version 4.5. Microcomputer Power, Ithaca, New York.

Thomas, J. A., E. E. Emery and F. H. McCormick. 2005. Detection of temporal trends in Ohio River fish assemblages based on lockchamber surveys, p. 431-449. In: J. N. Rinne, R. M. Hughes and B. Calamusso (eds.). Historical changes in large river fish assemblages of the Americas. American Fisheries Society, Bethesda, Maryland. 612 p.

Ward, J. V. And J. A. Stanford. 1983. The serial discontinuity concept of lotic ecosystems, p. 29-42. In: D. Fontaine and S. M. Bartell (eds.). Dynamics of lotic ecosystems. Ann Arbor Science, Ann Arbor, Michigan. 494 p. 